\title{
"Study on system fairness dimensions and tax compliance in the Middle East context"
}

Saeed Awadh Bin-Nashwan (D https://orcid.org/0000-0001-8919-4267

R http:/www.researcherid.com/rid/W-6643-2018

AUTHORS

Ahmed Mubarak Al-Hamedi

Munusamy Marimuthu

Abobakr Ramadhan Al-Harethi

Saeed Awadh Bin-Nashwan, Ahmed Mubarak Al-Hamedi, Munusamy Marimuthu

ARTICLE INFO and Abobakr Ramadhan Al-Harethi (2020). Study on system fairness dimensions and tax compliance in the Middle East context. Problems and Perspectives in Management, 18(1), 181-191. doi:10.21511/ppm.18(1).2020.16

DOI http://dx.doi.org/10.21511/ppm.18(1).2020.16

RELEASED ON

Monday, 02 March 2020

RECEIVED ON

Wednesday, 02 October 2019

ACCEPTED ON

Thursday, 06 February 2020

\section{$(\mathrm{cc}) \mathrm{EY}$}

LICENSE This work is licensed under a Creative Commons Attribution 4.0 International License

JOURNAL

"Problems and Perspectives in Management"

ISSN PRINT

$1727-7051$

ISSN ONLINE $1810-5467$

PUBLISHER

LLC "Consulting Publishing Company "Business Perspectives"

FOUNDER

LLC "Consulting Publishing Company "Business Perspectives"

NUMBER OF REFERENCES

43
NUMBER OF FIGURES

2
NUMBER OF TABLES

3

(C) The author(s) 2022. This publication is an open access article. 


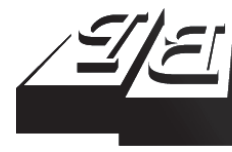

BUSINESS PERSPECTIVES

()

LLC "CPC "Business Perspectives" Hryhorii Skovoroda lane, 10, Sumy, 40022, Ukraine www.businessperspectives.org

Received on: $2^{\text {nd }}$ of October, 2019 Accepted on: $6^{\text {th }}$ of February, 2020 Published on: $2^{\text {nd }}$ of March, 2020

(C) Saeed Awadh Bin-Nashwan, Ahmed Mubarak Al-Hamedi, Munusamy Marimuthu, Abobakr Ramadhan Al_Harethi, 2020

Saeed Awadh Bin-Nashwan, Lecturer, Faculty of Administrative Sciences, Seiyun University, Seiyun, Yemen. (Corresponding author)

Ahmed Mubarak Al-Hamedi, Postgraduate Student, Tunku Puteri Intan Safinaz School of Accountancy, Universiti Utara Malaysia, Sintok, Malaysia.

Munusamy Marimuthu, Ph.D., Tunku Puteri Intan Safinaz School of Accountancy, Universiti Utara Malaysia, Sintok, Malaysia.

Abobakr Ramadhan Al_Harethi, Lecturer, Faculty of Administrative Sciences, Seiyun University, Seiyun, Yemen
Saeed Awadh Bin-Nashwan (Yemen), Ahmed Mubarak Al-Hamedi (Malaysia), Munusamy Marimuthu (Malaysia), Abobakr Ramadhan Al_Harethi (Yemen)

\begin{abstract}
People's perceptions of a fair tax administration system have garnered growing interest as a decisive ingredient that can install compliance behavior among taxpayers. The tax that taxpayers wish to evade is determined by their perceptions of the various robust dimensions of fairness (i.e., general fairness, preferred tax rate structure, exchange with the government, special provisions, and self-interest). Such an important matter, like tax fairness, has been overlooked in the extant literature, especially in the Middle East context, although tax administrations still suffer from low and unsatisfactory rates of compliance. This paper aims to empirically examine the influence of fairness perceptions of the income tax system on compliance behavior of taxpayers in Yemen. The study used a survey questionnaire administered to 400 individual taxpayers in Hadhramout, one of the most prosperous business regions in Yemen. Based on the PLS-SEM analysis tool, the study found that general system fairness, preferred tax rate, exchange with the government, and the extent of self-interest are significantly related to income tax compliance, while special provisions do not affect compliance decisions. The results of the study can alert the tax authority and policymakers to consider the non-pecuniary factors, other than the measures of the coercion. Establishing a fair tax system is probably one of the most successful approaches to boost compliance among taxpayers, thus yielding more tax revenue and diminishing the administrative cost for the tax authority.
\end{abstract}

\section{Keywords tax fairness dimensions, tax compliance, Middle East,} Yemen

JEL Classification H71, K42

\section{INTRODUCTION}

A sound understanding of tax compliance is crucial in both theory and practice. It has been acknowledged that a gambling model has been extensively used to examine taxpayers' compliance behavior (Jun, Cho, \& Park, 2015). This model assumes that taxpayers take the risk of the probability of being caught and penalized for evading their tax obligations they could report optimal levels of income by balancing the benefit of evading taxes and the cost of the potential sanctions imposed, especially when the tax authority detects non-compliance behavior. However, based on previous research, the dominant attribute of the economic approach (deterrence-based enforcement) is that it considers that the relationship between taxpayers and the authority is dependent on coercive treatment (Bordignon, 1993). This approach has not succeeded much in explaining a high level of tax compliance. Given the current levels of tax rate, audit, and penalty rate of many countries, people honestly report their taxable income and thus evade tax less than what is expected by the model (Alm et al., 1992; Bin-Nashwan, Abdul-Jabbar, \& Aziz, 2019; Gilligan \& Richardson, 2005; Slemrod \& Yitzhaki, 2002).

To address such inadequacies, the tax compliance phenomenon should be more satisfactorily explained by taking into account motivational 
approaches other than coercion (Azmi \& Perumal, 2008; Kirchgassner, 2011; Bordignon, 1993; Saad, 2011; Thomas, 2012). Some recent studies have introduced non-pecuniary determinants that considerably shape taxpayers' decisions to comply with tax regulations. It has been identified that taxpayers' perception of the tax system - as one of the fundamental non-economic attributes - plays a vital role in forming tax compliance behavior (Jackson \& Milliron, 1986; Richardson, 2006). Perhaps, the ineffectiveness of the tax system depends on the degree to which taxpayers perceive it to be inequitable and unfair, thus discouraging them from complying with tax payment. Globally speaking, the relationship between fairness perception of the tax system and compliance behavior has been widely examined in many countries (Jun et al., 2015; Saad, 2011; Gilligan \& Richardson, 2005); yet, it has been very rarely investigated in Middle East countries, including Yemen. Although tax revenue is one of the essential fiscal sources of Yemen's national income after oil, Yemen remains among countries with the lowest tax revenue. Total tax revenue in Yemen accounted for less than $9 \%$ as a share of the Gross Domestic Product (GDP) in 2014 compared to an average of 17.7\% in some similar developing economies, such as Egypt, Jordan, Morocco, Tunisia, and Algeria.

In Yemen, the Ministry of Planning and International Cooperation (MPIC) (2016) pointed out that the low tax collection is mainly attributed to the dilemma of taxpayers' low compliance and that seems to indicate an ineffective and inequitable tax system, weak tax provisions, low quality of public services in exchange for tax payment and rampant corruption (MPIC, 2016). The available statistics indicate that the tax non-compliance levels in Yemen are dramatically increasing year in and year out, leading to a huge loss of tax revenue, which could be employed to improve its national income, as well as eliminate the deficit in its budget. Clearly speaking, the amount of tax non-compliance was US\$ 164 million in 2004, reaching US\$ 2 billion in 2009. The levels of non-compliance showed an increasing trend from 2012 till 2016, recording a catastrophe loss at an annual average of almost US\$ 3 billion (MPIC, 2016). The lukewarm behavior of Yemeni taxpayers has continued to be distressing (Al-Ttaffi \& Abdul-Jabbar, 2018). Conclusively, this scenario has led to many unanswered questions as to what has accounted for this unenthusiastic non-compliance behavior. Thus, the present study aims to investigate how people in Yemen operationalize their evaluation and belief concerning the perceived dimensions of tax system fairness and their decisions to comply with tax laws. This paper is organized as follows: section 1 reviews the relevant theoretical background and hypotheses development. The research method is elaborated in section 2, while the results of the study and discussion are in sections 3 and 4, respectively. The conclusion, implications, limitations, and future directions are deliberated in the final section.

\section{LITERATURE REVIEW AND RESEARCH HYPOTHESES}

\subsection{Tax fairness dimensions and tax compliance}

According to the equity theory, a taxpayer perceives his/her relationship with the authority or government not only as one of coercion but also as a relationship of reciprocal exchange; they relinquish purchasing power for getting in return the publicly supplied services by the government (Bordignon, 1993). Extant studies have suggested that the taxpayers' perception of the tax system as being fair instills compliance behavior among them (Azmi \& Perumal, 2008; Alm, Jackson, \& McKee, 1992; Jun et al., 2015; Musimenta, Nkundabanyanga, Muhwezi, Akankunda, \& Nalukenge, 2017; Richardson, 2006; Saad, 2012; Spicer \& Becker, 1980). A taxpayer is inclined to avoid paying the required taxes if he/she perceives that the tax system is unfair (Spicer \& Becker, 1980). According to past literature, tax fairness is a term that has a universal definition. Christensen, Weihrich, and Newman (1994) stated that "fairness" is not easy to define; fairness is a multidimensional construct and can be identified at both individual and societal levels. Fairness is tangled with complexity, and the absence of fairness could be considered as a potential cause or justification for non-compliance behavior. As such, numerous studies proposed several dimensions of tax sys- 
tem fairness. For instance, by performing factor analysis and assessing the developed scales of fairness perceptions, Gerbing (1988) determined that five underlying dimensions of tax system fairness encompass: general system fairness, exchange or benefit from the state, special provisions, favored tax rates, and self-interest.

However, Wenzel (2003) identified that three types of fairness perceived by taxpayers from the social-psychological perspective are: retributive justice (i.e., applicable penalties when offenses are committed); distributive justice (i.e., benefit and cost exchanges); and procedural justice (i.e., measures of wealth allocation). Saad (2012) proposed seven dimensions to measure taxpayers' perceptions of tax system fairness, namely, general fairness (i.e., overall tax system evaluation); exchange fairness (i.e., reciprocal relationships between taxpayer and state); horizontal fairness (i.e., all taxpayers with similar economic positions are treated equally regarding tax payment); vertical fairness (i.e., taxpayers with different economic levels must be taxed differently); retributive fairness (i.e., fair punishment imposed); personal fairness (i.e., taxpayers' evaluation of the tax system, i.e., whether or not it is favorable); and administrative fairness (i.e., related to the tax law contents imposed by the tax authority).

In the Malaysian context, Hanefah (1996) appraised fairness perceptions of the previous income tax system, known as the official assessment system (OAS) on city and non-city taxpayers. The study found that non-city taxpayers have higher perceived fairness than city taxpayers. Azmi and Perumal (2008) undertook a research by adapting Gerbing's (1988) questionnaire to assess fairness perceptions, and they explored only three dimensions of tax fairness (self-interest, general fairness, and tax structure) as perceived by Malaysian taxpayers - without a further study on the influence of such dimensions on taxpayers' compliance. However, Saad (2011) compared Malaysian taxpayers to New Zealand taxpayers in terms of system fairness perception. Her findings revealed that Malaysian taxpayers show a better perception of tax system fairness than their counterparts in New Zealand, and yet, New Zealand taxpayers have a better level of compliance behavior. The multidimensional perspectives of tax fairness are not merely confined to direct taxes; it also in- cludes indirect taxes. This was empirically tested by Sinnasamy and Bidin (2017) who examined fairness perceptions in the Malaysian indirect tax environment from two aspects: the overall perceived fairness and fairness received from the state in a mutual relationship. The study attested that perceived tax fairness is negatively associated with tax non-compliance.

By agreeing that perceived tax fairness is a multidimensional factor, Bobek (1997) carried out a study on the tax system of the United States (US), examining procedural, policy, and distributive fairness. She concluded that policy fairness is a prerequisite for outcomes of distribution; it should be considered fair. Tax fairness plays a vital function in promoting tax compliance decisions. In a study on the perception of Dutch taxpayers of distributive fairness, Verboon and Dijke (2007) found moderate fairness in the tax system. Replicating Gerbing's (1988) work, Gilligan and Richardson (2005) found further evidence; they made a cross-cultural comparative study between results from Hong Kong and Australia and found several significant differences in fairness perceptions of the income tax systems, especially in terms of overall fairness, favored tax rate, special provision, and self-interest. Given the different nature of tax systems from one country to another, they also found differences in fairness perceptions. In a different study, Richardson (2006) also evidenced that taxpayers' compliance decisions are significantly formed by their perceptions of the tax system.

In a small developing economy, like Barbados, Thomas (2012) examined general fairness, exchange fairness, and self-interest, and demonstrated that general fairness is more relevant fairness dimension than the others. Thus, this could be an indicator of individuals' satisfaction with the implemented tax system, leading to boosting compliance and higher tax collections. Recent evidence from Nigeria provided by Gberegbe and Umoren (2017) indicated that general fairness, retributive fairness, distributive fairness, and procedural fairness are positively associated with income tax compliance. Likewise, Musimenta et al. (2017) found a strong relationship between system fairness and compliance behavior among Ugandan taxpayers. By using an experimental research design, Jun et al. (2015) found a tendency of the 
Korean people to evade tax less when they believe a majority voting role decides the structure of tax rate; thus, they concluded that tax system fairness affects compliance behavior positively. However, Mason and Calvin (1986) did not find the usually reported results of the relationship between tax compliance and fairness.

The relationship between perceived fairness of the tax system and individuals' compliance behavior remains unclear as evinced by the inconsistencies reported in past studies. Importantly, given the differences in tax systems, laws, sample selections, and methods used in prior studies, fairness in various countries is difficult to ascertain (Saad, 2012). To answer the call for urgent research to explore how tax fairness perceptions influence taxpayers' decision to comply with tax regulations in Middle East countries, the present study empirically examines the relationship between tax fairness (as a multidimensional construct) and compliance behavior among Yemeni taxpayers by adapting five developed dimensions of fairness, namely, general fairness, preferred tax rate structure, exchange with the government (i.e., benefits received from the government), special provisions, and self-interest. From the earlier discussion, the hypotheses are developed as follows:

H1: General fairness positively influences tax compliance behavior in Yemen.

H2: Preferred tax rate structure positively influences tax compliance behavior in Yemen.

H3: Exchange with government positively influences tax compliance behavior in Yemen.

H4: Special provisions positively influences tax compliance behavior in Yemen.

H5: Self-interest positively influences tax compliance behavior in Yemen.

\section{METHODS AND DATA}

\subsection{Data collection}

This research adopted a cross-sectional design using a self-administered survey for collecting the data. More precisely, the questionnaires were dis- tributed to taxpayers in the Hadhramout governorate, which is one of the largest and most prosperous business regions in Yemen (Bin-Nashwan, Abdul-Jabbar, \& Romle, 2016). A simple random sampling technique was used, targeting individual taxpayers in both private and public sectors. The population of this research constituted 20,470 taxpayers officially registered with the Yemen Tax Authority (2016). Based on the population size, the required sample size of this research was 400 (Krejcie \& Morgan, 1970). This also met the requirement of a minimum acceptable ratio based on the variables under study, as suggested by Hair, Sarstedt, Hopkins, and Kuppelwieser (2014). Out of the distributed questionnaires, 245 representing $61 \%$ were retrieved. A total of three responses was discarded as a result of double-clicking and bad completion of the questionnaire by participants. Thus, only 242 responses (60\%) were actually used for further analysis. This is considered adequate and acceptable for an environment like Yemen (Bin-Nashwan et al., 2017).

\subsection{Measurement}

A total of 25 measurement items was developed in the survey instrument for this research. The items were adapted from the studies of Richardson (2006) and Gerbing (1988) and adapted based on the present study's context and condition. All items used in the study were measured using the 5 -point Likert scale, ranging from $1=$ strongly disagree to $5=$ strongly agree. Before to pursuing the main research, a pre-testing or pilot study was carried out to detect and modify any ambiguities in the questions of the instrument; only minor modifications were made accordingly.

\subsection{Method of analysis}

In this study, Partial Least Squares-Structural Modelling Equation (PLS-SEM) was used to inspect the collected data. PLS-SEM can provide an efficient platform for evaluating an exploratory study. Hair, Hult, Ringle, and Sarstedt (2017) recommended PLS-SEM as a suitable data analysis tool in a study with non-normal data distribution. Using a Web application or "WebPower", the current research evaluated the multivariate normality in order to estimate coefficients and $p$-values of multivariate (Mardia's test) skewness and kur- 
tosis. The results demonstrated that the data are non-normal, as multivariate skewness and kurtosis $p$-values are below 0.05 . Consequently, the researchers proceeded with the use of PLS-SEM (Cain, Zhang, \& Yuan, 2017).

\section{RESULTS}

\subsection{Measurement model}

Hair et al. (2017) determined that two main models of PLS-SEM path analysis assessment are measurement (outer) and structural (inner) models. The analysis of assessing the measurement model consists of two main aspects: convergent and discriminant validity, which could facilitate researchers in determining the accuracy of the measurements used. Convergent validity is related to the indicators/items' internal consistency of each latent variable. To achieve convergent validity, all constructs' items must be in agreement; a set of items must measure the same construct in harmony. Henseler, Ringle, and Sinkovics (2009) also emphasized the analysis of convergent validity to ensure that all (items) indicators measure the cor- rect constructs in the model. The aspects inspected in convergent validity at the latent construct level comprise factor loadings, composite reliability, and average variance extracted (AVE).

As exhibited in Table 1 and Figure 1, the findings of this study indicate that all item loadings at least meet the 0.40 threshold value. For composite reliability, all construct values achieve the 0.70 threshold value. The lowest and highest composite reliability values are 0.860 (self-interest) and 0.921 (tax compliance), respectively. As for the AVE, all exogenous variables achieve the required threshold value of 0.50 (Hair et al., 2017). Hence, the results of this study reveal sufficient and satisfactory evidence of convergent validity.

Discriminant validity tests are used to ensure that a latent variable is grouped within its items only. This analysis is necessary for evaluating the measurement model to determine whether or not a construct is correct in terms of choosing a certain construct over the others (Hair et al., 2014). Fornell and Larcker's (1981) analysis is the first criterion applied to assess discriminant validity.

Table 1. Convergent validity

Source: Authors' compilation (2019).

\begin{tabular}{|c|c|c|c|c|}
\hline Latent variables & Items & Loadings & Composite reliability & AVE \\
\hline \multirow{5}{*}{ Tax compliance (TCOMP) } & TCOMP1 & 0.893 & \multirow{5}{*}{0.921} & \multirow{5}{*}{0.701} \\
\hline & TCOMP2 & 0.904 & & \\
\hline & TCOMP3 & 0.868 & & \\
\hline & TCOMP4 & 0.838 & & \\
\hline & TCOMP5 & 0.659 & & \\
\hline \multirow{4}{*}{ General fairness (GENF) } & GENF1 & 0.800 & \multirow{4}{*}{0.897} & \multirow{4}{*}{0.686} \\
\hline & GENF2 & 0.856 & & \\
\hline & GENF3 & 0.838 & & \\
\hline & GENF4 & 0.817 & & \\
\hline \multirow{4}{*}{ Preferred tax rate (TRAT) } & TRAT1 & 0.800 & \multirow{4}{*}{0.878} & \multirow{4}{*}{0.643} \\
\hline & TRAT2 & 0.816 & & \\
\hline & TRAT3 & 0.834 & & \\
\hline & TRAT4 & 0.757 & & \\
\hline \multirow{4}{*}{ Exchange with the government (EXCH) } & EXCH1 & 0.824 & \multirow{4}{*}{0.879} & \multirow{4}{*}{0.645} \\
\hline & $\mathrm{EXCH} 2$ & 0.846 & & \\
\hline & $\mathrm{EXCH} 3$ & 0.801 & & \\
\hline & $\mathrm{EXCH} 4$ & 0.738 & & \\
\hline \multirow{4}{*}{ Special provisions (SPEC) } & SPEC1 & 0.836 & \multirow{4}{*}{0.879} & \multirow{4}{*}{0.645} \\
\hline & SPEC2 & 0.780 & & \\
\hline & SPEC3 & 0.782 & & \\
\hline & SPEC4 & 0.813 & & \\
\hline \multirow{4}{*}{ Self-interest (SELF) } & SELF1 & 0.815 & \multirow{4}{*}{0.860} & \multirow{4}{*}{0.606} \\
\hline & SELF2 & 0.812 & & \\
\hline & SELF3 & 0.728 & & \\
\hline & SELF4 & 0.756 & & \\
\hline
\end{tabular}


Table 2. Discriminant validity

Source: Authors' compilation (2019).

\begin{tabular}{|c|c|c|c|c|c|c|}
\hline \multicolumn{7}{|c|}{ Discriminant validity (Fornell-Larcker criterion) } \\
\hline & TCOMP & GENF & TRAT & EXCH & SPEC & SELF \\
\hline TCOMP & 0.837 & & & & & \\
\hline GENF & 0.429 & 0.828 & & & & \\
\hline TRAT & 0.617 & 0.368 & 0.802 & & & \\
\hline $\mathrm{EXCH}$ & 0.768 & 0.382 & 0.524 & 0.803 & & \\
\hline SPEC & 0.467 & 0.286 & 0.425 & 0.477 & 0.803 & \\
\hline SELF & 0.730 & 0.406 & 0.642 & 0.718 & 0.504 & 0.779 \\
\hline \multicolumn{7}{|c|}{ Discriminant validity $\left(\mathrm{HTMT}_{0.90}\right)$} \\
\hline & TCOMP & GENF & TRAT & $\mathrm{EXCH}$ & SPEC & SELF \\
\hline \multicolumn{7}{|l|}{ TCOMP } \\
\hline GENF & 0.494 & & & & & \\
\hline TRAT & 0.724 & 0.441 & & & & \\
\hline $\mathrm{EXCH}$ & 0.894 & 0.459 & 0.639 & & & \\
\hline SPEC & 0.547 & 0.343 & 0.520 & 0.583 & & \\
\hline SELF & 0.873 & 0.495 & 0.801 & 0.897 & 0.627 & \\
\hline
\end{tabular}

Note: GENF: General fairness; TCOMP: Tax compliance; TRAT: Preferred tax rate; EXCH: Exchange with the government; SPEC: Special provisions; SELF: Self-interest.

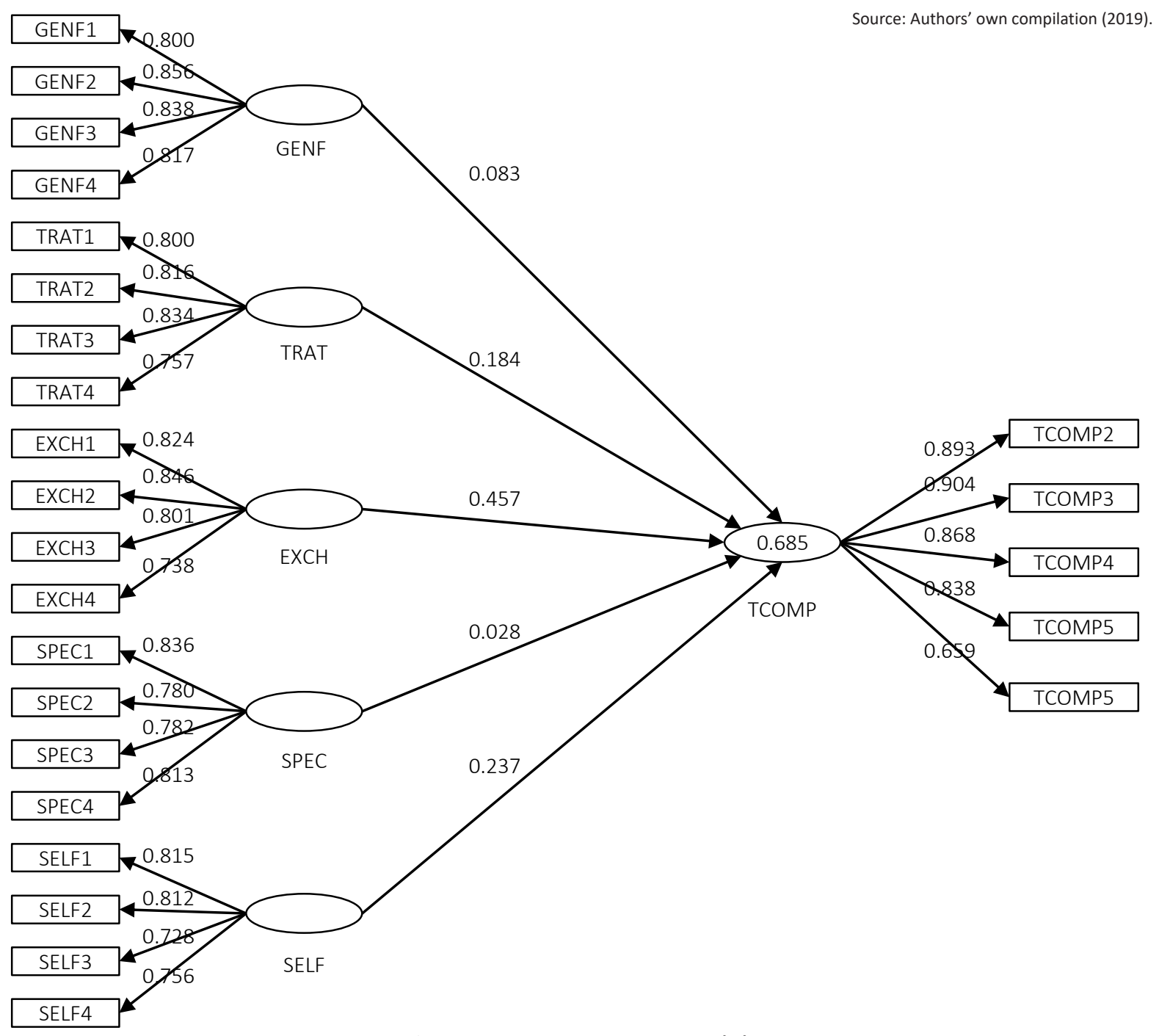

Figure 1. Measurement model 
Table 2 demonstrates the discriminant validity using the Fornell-Larcker criterion. Based on the findings, the square root of AVE is presented by the diagonal values (in bold), and it must be higher than all related inter construct correlation to affirm discriminant validity. The results display that the latent construct in the model is discriminant other constructs, and other items do not load on other constructs (Chin, 2010). In another extended analysis for discriminant validity, as recommended by Henseler et al. (2015), a new method for measuring the discriminant constructs is through the "Heterotrait-Monotrait (HTMT) ratio correlation." To achieve the required value of HTMT, its values must be less than HTMT $_{0.90}$ (Gold, Malhotra, \& Segars, 2001). Based on Table 2, all values are lower than the HTMT value of 0.90 , affirming that data in this research does not suffer from discriminant validity problem.

\subsection{Structural model}

Assessment of the structural model is the second part of the PLS path analysis. Hair et al. (2017) highlighted some essential inspections that encompass: collinearity among predictors, explained variance $\left(R^{2}\right)$ of endogenous construct, effect size $\left(f^{2}\right)$ of all relevant predictors, predictive relevance $\left(Q^{2}\right)$ of endogenous variable, and significance level of hypothesized relationships. In inspecting the collinearity of this study's structural model, the results exhibit the values of the variance inflation factor (VIF) for all latent constructs are less than the conservative threshold of five, i.e., in the range of 1.252 to 2.709 , indicating the absence of multicollinearity issue (Hair et al., 2014).

Given the explanatory nature of the present study, it was required to ensure that $R^{2}$ values (i.e., the explained variance in the endogenous variable) is maximized (Hair et al., 2017). The $R^{2}$ value of the endogenous variable (tax compliance) is 0.685 (see Figure 1). This reflects that the model tested in this research shows adequate predictive relevance (Cohen, 1988). The $f^{2}$ was also assessed to determine whether the omission of a certain exogenous variable leads to a change in $R^{2}$. To assess the $f^{2}$ magnitude, the present study employed Cohen's (1988) guideline for exogenous constructs - values of $f^{2}$ of $0.02,0.15$, and 0.35 indicate the effect magnitude to be small, medium, and large, respectively. The findings show that exchange with the government has medium $f^{2}$ of 0.302 . Small values of $f$ are found in self-interest, preferred tax rate, and overall fairness $(0.066,0.060$, and 0.017 , respectively), while no effect is demonstrated for special provisions (0.002). The study also tested the predictive relevance $\left(Q^{2}\right)$ by performing the blindfolding technique in Smart PLS to assess the Stone-Geisser's $Q^{2}$ analysis (Geisser, 1974). The value of $Q^{2}$ of the endogenous construct (tax compliance) is higher than zero $\left(Q^{2}=0.441\right)$, signifying the model's predictive relevance.

The significance levels of the hypothesized relationships were assessed by applying 5,000 bootstrap sub-samples. Table 3 and Figure 2 show that the structural relationship between general fairness and tax compliance results is $(\beta=0.083$, $t=2.115, p=0.017$ ). Similarly, the association between preferred tax rate structure and compliance indicates $(\beta=0.184, t=2.932, p=0.002)$. The association between fair reciprocal exchange with the state and compliance behavior is $(\beta=0.457$, $t=7.931, p=0.000$ ). Likewise, self-interest and individual taxpayers' compliance behavior is $(\beta=0.237, t=3.607, p=0.000)$. However, the path from special provisions to tax compliance demonstrates $(\beta=0.028, t=0.644, p=0.260)$. It is therefore concluded that all the hypothesized relation-

Table 3. Structural model

Source: Authors' compilation (2019).

\begin{tabular}{|c|c|c|c|c|c|c|}
\hline Relationship & $\beta$ & St-Dev. & $t$-value & $p$-value & $f^{2}$ & VIF \\
\hline H1: GENF $\rightarrow$ TCOMP & 0.083 & 0.039 & 2.115 & 0.017 & 0.017 & 1.251 \\
\hline H2: TRAT $\rightarrow$ TCOMP & 0.184 & 0.063 & 2.932 & 0.002 & 0.060 & 1.787 \\
\hline H3: EXCH $\rightarrow$ TCOMP & 0.457 & 0.058 & 7.931 & 0.000 & 0.302 & 2.190 \\
\hline H4: SPEC $\rightarrow$ TCOMP & 0.028 & 0.044 & 0.644 & 0.260 & 0.002 & 1.422 \\
\hline H5: SELF $\rightarrow$ TCOMP & 0.237 & 0.066 & 3.607 & 0.000 & 0.066 & 2.709 \\
\hline
\end{tabular}

Note: GENF: General fairness; TCOMP: Tax compliance; TRAT: Preferred tax rate; EXCH: Exchange with the government; SPEC: Special provisions; SELF: Self-interest; f²: Effect size; VIF: Variance inflation factor. 


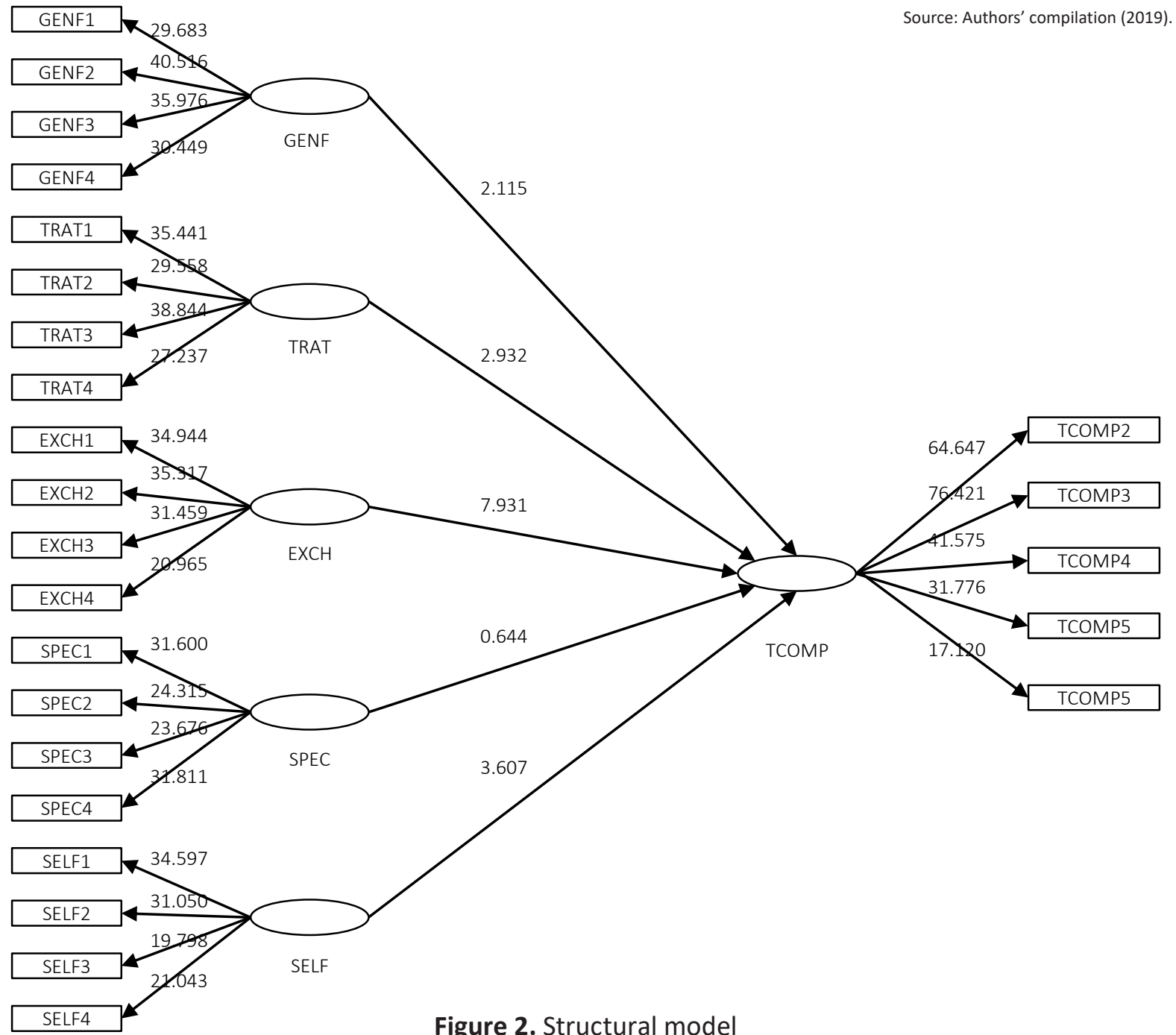

ships of the study's model are positively significant, except the relationship between special provisions and compliance. Consequently, the structural model provides evidence that supports $\mathrm{H1}, \mathrm{H} 2, \mathrm{H3}$ and $H 5$, while it does not support $H 4$.

\section{DISCUSSION}

In an attempt to bridge the research gap in the previous studies, i.e., the lack of empirical evidence on the influence of fairness perceptions of tax system in the Middle East region, this study attempts to shed light on the influence of fairness perceptions of Yemeni taxpayers of the current tax system and the likelihood of their compliance behavior. Drawing upon the effort of Gerbing (1988) as a starting point, five robust dimensions of tax fairness were identified relating to general fairness, favored tax rate, exchange with the govern- ment, special provisions, and extent of self-interest. Remarkably, the findings of the present study revealed that all these five dimensions of fairness collectively explain $68.5 \%$ of the variance level of Yemeni taxpayers' compliance behavior.

The empirical evidence of this study has provided interesting findings. It revealed that while taxpayers perceive all the tax fairness dimensions in Yemen, general fairness, preferred tax rate structure, exchange with the government and extent of self-interest dimensions, are positive and significant determinants of tax fairness and taxpayers' compliance behavior. The special provisions variable had no effect. The results in this research are consistent with previous studies (Chan, Troutman, \& O’Bryan, 2000; Faizal \& Palil, 2015; Gilligan \& Richardson, 2005; Richardson, 2006; Saad, 2010), contending that taxpayers believe that tax system fairness is shaped by various perceptions and 
viewpoints, the most significant being general fairness, favored tax rates structure, fair reciprocal exchange with the state or government and self-interest, that lead to greater tax compliance behavior.

Chan et al. (2000) give evidence that taxpayers' fairness perception of the tax system is positively associated with compliance behavior. Faizal and Palil (2015) also revealed that compliance behavior of taxpayers could be shaped through a fair tax system. Richardson (2006) explicitly supported the fact that the public perceives fairness in any tax system as an important determinant constituting voluntary tax compliance. People are normally inclined not to comply with tax laws and rules if they believe that the tax system does not have well-established fairness principles. Richardson (2006) indicated that while all the five dimensions of tax system fairness, adapted from Gerbing's (1988) study conducted in the US exist in the context of Hong Kong, the general fairness, the benefit received from the government and preferred tax rate structure are the most significant dimensions of tax system fairness. Special provisions and self-interest for high-income earners have the lowest significance. The present research also found that perceived special provisions do not significantly affect the Yemeni taxpayers' compliance. Perhaps, since there are cultural and educational differences in the Middle East countries (e.g., Yemen) compared to the Western context, this could be a rational justification and explanation for this slightly different result reported concerning tax fairness perceptions. Equally, some concepts of tax fairness and its dimensions may be difficult for the average taxpayers to understand easily.

\section{CONCLUSION}

The paper provides empirical evidence on how the tax fairness dimensions can explain the tax compliance puzzle in one of the Middle East countries, i.e., Yemen. By adopting cross-sectional research based on a survey of individual taxpayers in Yemen - consistent with prior studies - this study found that general system fairness, favored tax rate, exchange and reciprocal relationship with the government and extent of self-interest have a significant relationship with taxpayers' decisions to comply with tax provisions. Thus, these perceptions play a crucial, and perhaps, even a dominant role, in compliance behavior.

The results of this research would be of interest to the tax authorities, and other practitioners not only in Yemen but also in other Arab, Middle East, and developing countries. Instead of expanding the resources on enforced compliance through more penalties and audit, the tax authorities can consider strategies and policies to ensure fairness in all features of the tax system to diminish non-compliance behavior. Importantly, it is imperative for the tax authorities to initiate a fair tax system and administration simply. While this study has attained its objective, some limitations should be highlighted for future research. The present study focused only on tax fairness perceptions; to have complete explanation of the compliance model, future researchers must examine further determinants to improve voluntary compliance behavior, other than coercion (e.g., social norms, trust, and moral values). It could also be claimed that this study is one of very few that investigates the effect of tax fairness dimensions in the Middle East context. This scarcity of similar studies limits the study's ability to benchmark its findings with other prior studies in the same context. It is possible to extend the study's model to some other Arab and Middle Eastern communities.

\section{REFERENCES}

1. Alm, J., Jackson, B. R., \& McKee, M. (1992). Estimating the determinants of taxpayer compliance with experimental data. National Tax Journal, 7(1), 107-114. Retrieved from https:// ideas.repec.org/a/ntj/journl/v45y1992ilp107-14.html
2. Alm, J., McClelland, G., \& Schulze, W. (1992). Why do people pay their taxes? Journal of Public Economics, 48(1), 21-38. https://doi.org/10.1016/00472727(92)90040-M

3. Al-Ttaffi, L. H. A., \& Abdul-Jabbar, H. (2018). Geopolitical differences and tax non-compliance among Yemeni SMEs. Journal of Business Management and Accounting, 8(1), 31-45. Retrieved from http://www. imbre.uum.edu.my/images/31-45. pdf

4. Azmi, A. A., \& Perumal, K. A. (2008). Tax Fairness 
Dimensions in an Asian Context: The Malaysian Perspective. International Review of Business Research Papers, 4(5), 11-19. Retrieved from https://www. researchgate.net/publication/242288892_Tax_Fairness_Dimensions_In_An_Asian_Context_The_Malaysian_Perspective

5. Bin-Nashwan, S. A., AbdulJabbar, H., \& Aziz, S. A. (2019). Do enforcement, religiosity and peer influence zakah compliance behavior? International Journal of Financial Research, 10(6), 4253. https://doi.org/10.5430/ijfr. v10n6p42

6. Bin-Nashwan, S. A., AbdulJabbar, H., \& Romle, A. R. (2016). The application of theory of planned behavior on business zakah compliance in Yemen: A proposed framework. MiddleEast Journal of Scientific Research, 24(6), 2052-2057. Retrieved from https://www.researchgate.net/ publication/311614091_The_Application_of_Theory_of_Planned_ Behaviour_on_Business_Zakah_ Compliance_in_Yemen_A_Proposed_Framework

7. Bin-Nashwan, S. A., AbdulJabbar, H., \& Romle, A. R. (2017). Perception of business owner toward business zakah compliance intention. World Journal of Islamic History and Civilization, 7(2), 17 22. Retrieved from https://idosi. org/wjihc/wjihc7(2)17/1.pdf

8. Bobek, D. D. (1997). Tax Fairness: How do individuals judge fairness and what effect does it have on their behavior? (Unpublished thesis). University of Florida, Michigan.

9. Bordignon, M. (1993). A fairness approach to income tax evasion. Journal of Public Economics, 52(3), 345-362. https://doi. org/10.1016/0047-2727(93)90039$\mathrm{V}$

10. Cain, M. K., Zhang, Z., \& Yuan, K. H. (2017). Univariate and multivariate skewness and kurtosis for measuring nonnormality: prevalence, influence and estimation. Behavior Research Methods, 49(5), 1716-1735. https://doi.org/10.3758/s13428016-0814-1
11. Chan, C. W., Troutman, C. S., \& O'Bryan, D. (2000). An expanded model of taxpayer compliance: empirical evidence from the United States and Hong Kong. Journal of International Accounting, Auditing and Taxation, 9(2), 83-103. https:// doi.org/10.1016/S10619518(00)00027-6

12. Chin, W. W. (2010). How to write up and report pls analyses. Handbook of Partial Least Squares. Springer, Berlin, Heidelberg. Retrieved from https://link. springer.com/chapter/10.1007\% 2F978-3-540-32827-8_29

13. Christensen, A. L., Weihrich, S. G., \& Newman, M. G. (1994). The impact of education on perceptions of tax fairness. Advances in Taxation, 6, 63-94.

14. Cohen, J. (1988). Statistical power analysis for the behavioral sciences (2nd ed.). Lawrence Erlbaum Associates, Hillsdale.

15. Faizal, S., \& Palil, M. R. (2015). Study on fairness and individual tax compliance in Malaysia: Preliminary fndings. International Journal of Business, Economics and Law, 8(1), 74-79. Retrieved from https://www.ijbel.com/wp-content/uploads/2016/01/Acc-35.pdf

16. Fornell, C., \& Larcker, D. (1981). Evaluating structural equation models with unobservable variables and measurement error. Journal of Marketing Research, 18(1), 39-50. https:// journals.sagepub.com/ doi/10.1177/002224378101800104

17. Gberegbe, F. B., \& Umoren, A. O. (2017). The perception of tax fairness and personal income tax compliance of SMEs in Rivers State. Journal of Research in Business and Management, 5(2), 40-51. Retrieved from https://pdfs. semanticscholar.org/5e 53/6ef9c1 6bbfd1eb0450bc59b2823236383 8bb.pdf

18. Geisser, S. (1974). Predictive approach to the random effect model. Biometrika, 61(1), 101-107. https://doi.org/10.1093/biomet/61.1.101
19. Gerbing, M. D. (1988). An empirical study of taxpayer perceptions of fairness (Unpublished thesis). University of Texas, Austin.

20. Gilligan, G., \& Richardson, G. (2005). Perceptions and tax compliance behavior in Australia and Hong Kong - A preliminary study. Journal of Financial Crime, 31(1), 11-67. https://doi. org/10.1108/13590790510624783

21. Gold, A. H., Malhotra, A., \& Segars, A. H. (2001). Knowledge management: An organizational capabilities perspective. Journal of Management Information Systems, 18(1), 185-214. https://doi.org/10. 1080/07421222.2001.11045669

22. Hair, J. F., Hult, G. T., Ringle, C. M., \& Sarstedt, M. (2017). A primer on partial least squares structural equation modeling (PLSSEM) (2nd ed). London: Sage Publications.

23. Hair, J. F., Sarstedt, M., Hopkins, L., \& Kuppelwieser, V. (2014). Partial least squares structural equation modeling (PLS-SEM): An emerging tool in business research. European Business Review, 26(2), 106-121. https://doi. org/10.1108/EBR-10-2013-0128

24. Hanefah, H. M. B. M. (1996). An evaluation of the Malaysian tax administrative system and tax payers' perceptions towards assessment systems, tax law fairness, and tax law complexity (Unpublished thesis). Universiti Utara Malaysia. Retrieved from http://etd.uum.edu.my/

25. Henseler, J., Ringle, C. M., \& Sarstedt, M. (2015). A new criterion for assessing discriminant validity in variancebased structural equation modeling. Journal of the Academy of Marketing Science, 43(1), 115 135. Retrieved from https://link. springer.com/article/10.1007\%2 Fs11747-014-0403-8

26. Henseler, J., Ringle, C. M., \& Sinkovics, R. R. (2009). The use of partial least squares path modeling in international marketing. New Challenges to International Marketing, 20, 277-319. https:// doi.org/10.1108/S14747979(2009)0000020014 
27. Jackson, B. R., \& Milliron, V. C. (1986). Tax compliance research finding, problem and prospect. Journal of Accounting Literature, 5(1), 125-165.

28. Jun, B. H., Cho, M., \& Park, M. H. (2015). Procedural fairness and taxpayers' response: Evidence from an experiment. Korean Economic Review, 31(2), 301326. Retrieved from http:// www.kereview.or.kr/modules/ repec/backIssue_view.html$? \mathrm{vol}=31 \&$ num $=2 \& \mathrm{p}=1 \& \mathrm{no}=550$

29. Kirchgassner, G. (2011). Tax morale, tax evasion and the shadow economy. Handbook on the Shadow Economy. Retrieved from https://ideas.repec.org/h/elg/eechap/13432_10.html

30. Krejcie, R. V., \& Morgan, D. W. (1970). Determining sample size for research activities. Educational and Psychological Measurement, 30(3), 607-610. https://doi. org/10.1177/001316447003000308

31. Mason, R., \& Calvin, L. (1986). Public confidence and admitted tax evasion. National Tax Journal, 37(4), 489-496. Retrieved from https://search.proquest.com/ docview/207198512/fulltextPDF/ 86A944A54263437APQ/1?accoun tid $=42599$

32. Ministry of Planning \& International Cooperation (MPIC). (2016). Annual Report. Retrieved from http://www.yemen.gov.ye/portal/ (accessed on October 24, 2017).

33. Musimenta, D., Nkundabanyanga, S. K., Muhwezi, M., Akankunda B., \& Nalukenge, I. (2017). Tax compliance of small and medium enterprises: A developing country perspective. Journal of Financial Regulation and Compliance, 25(2), 149-175. https://doi.org/10.1108/ JFRC-08-2016-0065

34. Richardson, G. (2006). The impact of tax fairness dimensions on tax compliance behavior in an Asian jurisdiction: The case of Hong Kong. International Tax Journal, 32(1), 29-42.

35. Saad, N. (2011). Fairness perceptions and compliance behaviour: taxpayers' judgments in self-assessment environments (Unpublished thesis). University of Canterbury. Retrieved from https://www.canterbury.ac.nz/

36. Saad, N. (2012). Information dissemination and fairness perceptions: The case of Inland Revenue Board Malaysia. In Knowledge Management International Conference (pp. 4-6). Johor Bahru, Malaysia. Retrieved from https://core.ac.uk/download/ pdf/20257858.pdf

37. Sinnasamy, P., \& Bidin, Z. (2017). The relationship between tax rate, penalty rate, tax fairness and excise duty non-compliance. SHS Web of Conferences, 34, 11001. https://doi.org/10.1051/ shsconf/20173411001

38. Slemrod, J., \& Yitzhaki, S. (2002). Tax avoidance, evasion, and administration. Handbook of Public Economics, 3, 1423-1470. https://doi.org/10.1016/S15734420(02)80026-X

39. Spicer, M. W., \& Becker, L. A. (1980). Fiscal inequity and tax evasion: An experimental approach. National Tax Journal, 171-175. Retrieved from https://search.proquest. com/docview/207205362?pqorigsite $=$ gscholar

40. Thomas, C. (2012). Assessing tax fairness dimensions in a small developing economy. Business and Economics Journal, 3(1), 1-8. Retrieved from https://www. omicsonline.org/open-access/ assessing-tax-fairness-dimensionsin-a-small-developing-economy-2151-6219-3-062.pdf

41. Verboon, P., \& Dijke, M. Van. (2007). A self-interest analysis of justice and tax compliance: How distributive justice moderates the effect of outcome favorability. Journal of Economic Psychology, 28, 704-727. https://doi.org/10.1016/j. joep.2007.09.004

42. Wenzel, M. (2003). Tax compliance and the psychology of justice: Mapping the field. In V. Braithwaite (Ed.), Taxing
Democracy. Understanding tax avoidance and tax evasion (pp. 41-69). Aldershot: Ashgate. Retrieved from http://hdl.handle. net/2328/13626

43. Yemen Tax Authority. (2016). Annual report. Statistics of registered taxpayers. Retrieved from https://www.tax.gov.ye/ 